\title{
Hydraphiles Enhance Antimicrobial Potency Against Escherichia coli, Pseudomonas aeruginosa, and Bacillus subtilis
}

Mohit B. Patel, ${ }^{\uparrow \ddagger}$ Evan C. Garrad, ${ }^{\ddagger}$ Ariel Stavri, ${ }^{\ddagger}$ Michael R. Gokel,,*ף Saeedeh Negin, ${ }^{9^{\natural \dagger}}$ Joseph W. Meisel, ${ }^{9^{\dagger}}$ Zachary Cusumano, ${ }^{\S}$ and George W. Gokel ${ }^{q \neq * \# \#}$

${ }^{\top}$ Center for Nanoscience, Departments of ${ }^{\dagger}$ Chemistry \& Biochemistry and ${ }^{*}$ Biology, University of Missouri - St. Louis, 1 University Blvd., St. Louis, MO 63121; ' 'Department of Cell Biology, Washington University School of Medicine, St. Louis, MO 6311o; and "Upaya Pharmaceuticals, LLC, 4633 World Pkwy. Cir., Berkeley, MO 63134

Submitted to Bioorganic and Medicinal Chemistry

March 1, 2016

Revised version submitted April 19, 2016

Corresponding author

G. W. Gokel

Center for Nanoscience

Department of Chemistry \& Biochemistry

University of Missouri-St. Louis

St. Louis, MO 63121 USA

Tel. $\quad 314 / 516-5321$

Fax 314/516-5342

E-mail: gokelg@umsl.edu 


\begin{abstract}
Hydraphiles are synthetic amphiphiles that form ion-conducting pores in liposomal membranes. These pores exhibit open-close behavior when studied by planar bilayer conductance techniques. In previous work, we showed that when coadministered with various antibiotics to the $\mathrm{DH}_{5} \alpha$ strain of $E$. coli, they enhanced the drug's potency. We report here potency enhancements at low concentrations of hydraphiles for the structurally and mechanistically unrelated antibiotics erythromycin, kanamycin, rifampicin, and tetracycline against Gram negative $E$. coli (DH5 $\alpha$ and K-12) and Pseudomonas aeruginosa, as well as Gram positive Bacillus subtilis. Earlier work suggested that potency increases correlated to ion transport function. The data presented here comport with the function hydraphiles to enhance membrane permeability in addition to, or instead of, their known function as ion conductors.
\end{abstract}

\title{
Graphical Abstract
}

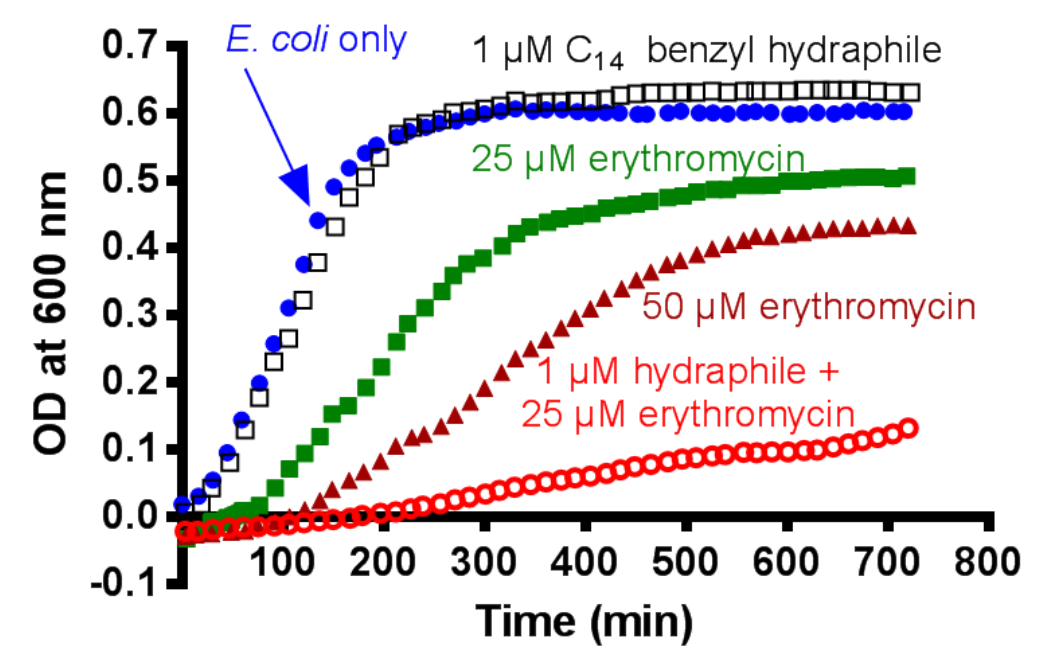




\section{Introduction}

Since the development of the sulfa drug Prontosil in the 1930s, antibiotic therapy has produced a revolution in the treatment of infections. ${ }^{1}$ Sulfa drugs were largely replaced in the 1940 s by penicillin derivatives and a range of subsequent antibiotics such as the cephalosporins and the fluoroquinolones. By the 1960s, it was generally believed that the bacterial infection war had been won. In the interim, the emergence of antibiotic resistance has become an international crisis. ${ }^{2}$ Both the Centers for Disease Control and Prevention (CDC) 3 and the World Health Organization (WHO) 4 have issued extensive advisories and discussions concerning the current problems.

The problem has been exacerbated by the lack of new antibiotic derivatives and antibiotic classes (new chemical entities). Encouraging recent results have appeared, however, with the reports of teixobactin 5 and aspergillomarasmine A. ${ }^{6}$ In addition, such antibiotic peptides ${ }^{7}$ as magainin ${ }^{8}$ and derivatives along with various cationic amphiphiles 9 have been extensively studied in recent years. Combinations of antibiotics and peptide antibiotics have been used against both Gram negative and Gram positive bacteria. ${ }^{10}$ Notwithstanding, the problem of antibiotic resistance persists and its threat to worldwide health is increasing.

In a preliminary report, ${ }^{11}$ we showed that hydraphiles, ${ }^{12}$ when co-administered with various antibiotics, enhanced the potency of the drugs against the microbes. The original hypothesis that potency enhancement was possible was based on the membrane activity of hydraphiles. ${ }^{13}$ It was surmised that the insertion of hydraphiles into a bacterial boundary layer would create an opening or defect that might permit other molecules to more readily penetrate it. We chose antibiotics as the test substance because bacteriostatic or bactericidal activity would serve as a useful metric to evaluate the hypothesis. We report here an extensive elaboration of our original study to a number of antibiotic/amphiphiles/organism combinations. In some cases, potency enhancements were found to be as high as 30-fold.

\section{Results and Discussion}

In the nearly half century since the discovery of crown ethers, ${ }^{14}$ there have been numerous reports of biological activity. Early studies showed, for example that exposure to 12-crown-4 caused testicular atrophy in mice. ${ }^{15}$ More extensive studies showed that the simple crowns 12-crown-4, 15-crown-5, and 18-crown-6 had $\mathrm{LD}_{50}$ values (male white rats) of 3200,1000 , and $700 \mathrm{mg} / \mathrm{kg}$, respectively. ${ }^{16}$ Antibacterial ${ }^{17}$ and antifungal ${ }^{18}$ activities of widely varied crown structures were reported in the early 1980s. Additional antimicrobial activity of various crown ether derivatives has been reported up to the present day. ${ }^{19}$ The diverse ranges of structures and organisms that have been studied make it difficult to generalize about crown toxicity in the absence of other substances. To the extent a conclusion can be articulated, it is that crown toxicity to Gram positive organisms such as $B$. subtilis is likely to be greater than to Gram negative organisms such as E. coli.

Our own studies of antimicrobial activity of hydraphiles showed the presence of the amphiphilic pore formers in the E. coli boundary layer. ${ }^{20}$ A study of activity 
against $E$. coli and $B$. subtilis revealed a correlation between hydraphile length and toxicity. ${ }^{13}$ Hydraphile length also correlates to efficacy of ion transport. ${ }^{21}$ Because of the correlation that we observed between ion transport activity and toxicity to $E$. coli, we examined a shorter-chained hydraphile that should be a poor channelformer to test its effect. The results of these studies are described below.

Compounds used. The work reported here used three different hydraphiles. ${ }^{22}$ They are illustrated in Figure 1 as 1-3. The spacer chains represented in Figure 1 by $\left(\mathrm{CH}_{2}\right)_{\mathrm{n}}$ had values of $\mathrm{n}$ equal to 8,14 , and 16 . In all cases, the two distal macrocycles were benzyl-terminated. We refer to these hereinafter as benzyl $\mathrm{C}_{8}(\mathbf{1})$, benzyl $\mathrm{C}_{14}(\mathbf{2})$ and benzyl $\mathrm{C}_{16}(\mathbf{3})$ hydraphiles. All three compounds used have been fully characterized and all are previously known. ${ }^{22,23}$

The antibiotics used were kanamycin sulfate [4, kanamycin D, mixture of (predominantly) A, B, and C], tetracycline (5), erythromycin (6) and rifampicin (7). These four antibiotics were obtained from commercial suppliers in the purest form available and used as received. They were selected because their chemical structures are very different. For each of the antibiotics, the mechanism of action is both well-established and different from any of the other compounds used in this study. Kanamycin A is an aminoglycoside that inhibits protein synthesis and cell respiration and causes potassium cation leakage to occur. ${ }^{24}$ Tetracycline, which is produced in vast quantities annually, binds to the $30 \mathrm{~S}$ ribosomal subunit, which inhibits peptide synthesis. ${ }^{25}$ To the extent that any of the structures are related, it is erythromycin and rifampicin, both of which are macrolides. The ring sizes are vastly different as are the substitution patterns and modes of action.

Erythromycin ${ }^{26}$ inhibits protein synthesis by binding to the ribosomal $50 \mathrm{OS}$ subunit. Rifampicin, ${ }^{27}$ in contrast, inhibits RNA synthesis. Although both erythromycin and rifampicin ultimately inhibit protein synthesis, they do so by distinctly different interactions and mechanisms. Their different modes of action are reflected in their different indications. Rifampicin is a first line treatment for tuberculosis ${ }^{28}$ and erythromycin is prescribed for such conditions as bronchitis and pertussis. ${ }^{29}$ What all four antibiotics do have in common is that they all must infiltrate the cell cytoplasm to inhibit bacterial growth.

The activities of all compounds were assayed by determining the minimum inhibitory concentrations (MICs) under specified conditions. All MIC determinations were conducted according to the protocols provided by the Clinical and Laboratory Standards Institute: Mo7-A9. ${ }^{30}$ We note for the reader unfamiliar with this assay that the procedure depends on bacterial growth observed in a sequence of serial dilutions. Thus, a minimum inhibitory concentration may be 4 $\mu \mathrm{M}$ in one determination, $8 \mu \mathrm{M}$ in a second, and $2 \mu \mathrm{M}$ in a third. In our studies, we typically conducted between 3-5 replicates to determine a reproducible MIC, which would be reported as $4 \mu \mathrm{M}$ for the example given above.

The MIC was also determined for the commercial amphiphile Triton X-10o (8). This is a common neutral detergent that has been reported to be membrane active. ${ }^{31}$ It was included as a control to assess whether the effects observed for hydraphiles are essentially generic and would be manifested by any membrane 
active amphiphile. The choice of Triton X-10o was also based on reports of channel-like function under certain conditions in liposomal membranes.32,33 The oligoethylene glycol chain of Triton X-100 varies from 9-10 units, giving an average molecular weight of 625 Daltons. This value was used in minimum inhibitory concentration (MIC) determinations.
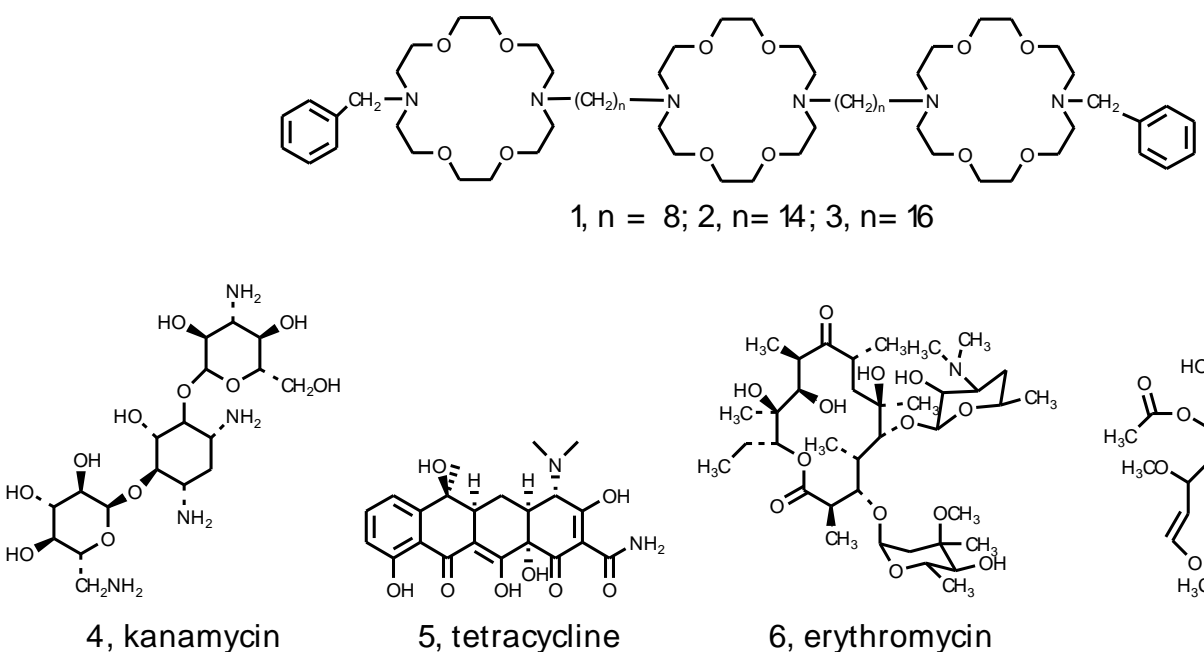

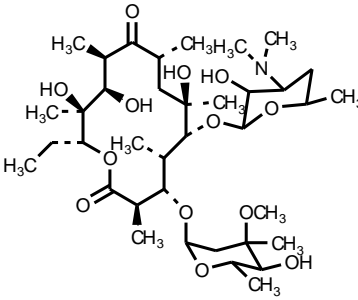

6 , erythromycin

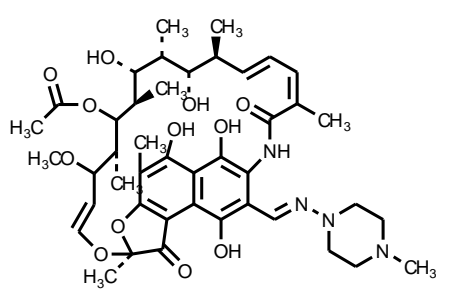

7, rifampicin

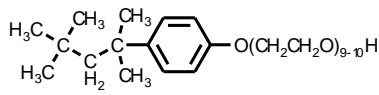

8, Triton X-100

Figure 1. Structures of hydraphile (1-3), kanamycin (4), tetracycline (5), erythromycin (6), rifampicin (7) and Triton X-100 (8).

Bacteria used. Four different microbial strains were used to study antibacterial activity. All of the synergy studies previously reported with benzyl $\mathrm{C}_{14}$ hydraphile and antibiotics were against the $\mathrm{DH}_{5} \alpha$ E. coli strain. ${ }^{11}$ This non-pathogenic strain of $E$. coli has been optimized for laboratory use in molecular biology experiments. Results are recorded herein for that strain but new results are presented for $E$. coli (Migula) Castellani and Chalmers (MG1655) K-12 strain. K-12 E. coli is derived from a human stool sample and is generally considered to be more robust than DH5a E. coli. The other two bacteria studied were Gram negative Pseudomonas aeruginosa and Gram positive B. subtilis. Pseudomonas is often found in biofilms 34 and is a common infection in patients using hospital breathing machines (i.e. ventilator-associated pneumonia). We used B. subtilis to assess the efficacy of our combination therapy in a Gram-positive bacterium.

Determination of hydraphile toxicity. We determined the MICs for each compound against E. coli (DH5a), E. coli (K-12), P. aeruginosa and B. subtilis. Gram negative $\mathrm{DH}_{5}$ a E. coli was used as a control and to compare the synergy data of benzyl $\mathrm{C}_{8}$ hydraphile (1) to that of the values previously reported for benzyl $\mathrm{C}_{14}$ hydraphile (2). 35 This is important to be sure that bacterial strains kept in storage 
have not been compromised. The MIC data are recorded in Table 1 for the hydraphiles (1-3), the antibiotics (4-7), and Triton X-100 (8).

Table 1. MICs of hydraphiles and antibiotics against $E$. coli (DH5 $\alpha$ and K-12), $P$. aeruginosa and B. subtilis.

\begin{tabular}{|c|c|c|c|c|}
\hline $\begin{array}{c}\text { Benzyl } \\
\text { hydraphile used }\end{array}$ & $\begin{array}{c}\text { E. coli } \\
(\mathrm{DH} 5 \alpha, \mu \mathrm{M})\end{array}$ & $\begin{array}{c}\text { E. coli } \\
(\mathrm{K}-12, \mu \mathrm{M})\end{array}$ & $\begin{array}{l}\text { P.aerug- } \\
\text { inosa }(\mu \mathrm{M})\end{array}$ & $\begin{array}{l}\text { B. subtilis } \\
(\mu \mathrm{M})\end{array}$ \\
\hline $\mathrm{C}_{8}$ hydraphile (1) & 300 & 200 & $\mathrm{ND}$ & ND \\
\hline $\mathrm{C}_{14}$ hydraphile (2) & 2 & 2.5 & 2 & 0.5 \\
\hline $\mathrm{C}_{16}$ hydraphile (3) & 4 & ND & 2 & ND \\
\hline Kanamycin (4) & 30 & 35 & ND & ND \\
\hline Tetracycline (5) & 5 & 5 & 12 & 3 \\
\hline Erythromycin (6) & 200 & 700 & 200 & 0.3 \\
\hline Rifampicin (7) & 55 & 16 & 25 & ND \\
\hline Triton X-100 (8) & $>512$ & $>512$ & ND & ND \\
\hline
\end{tabular}

It is interesting to note that an extensive literature spanning many years shows that structurally diverse crown ethers are toxic to a range of microbes and higher cells. The variations in macrocycle, organism, and analytical methods used make it difficult to reach a firm conclusion about toxicity. To the extent such a conclusion can be reached for bacteria, it is that crowns of various types are generally more toxic to Gram positive than to Gram negative strains. We observe a similar situation with benzyl $\mathrm{C}_{14}$ hydraphile. Note that the potency difference between benzyl $\mathrm{C}_{16}$ hydraphiles against $E$. coli $\mathrm{DH}_{5} \alpha$ and $P$. aeruginosa is a single dilution in the MIC analysis, although variation in responses of different strains of bacteria to xenobiotics is common.

Synergy against $E$. coli (DH5 $\alpha$ and K-12), $P$. aeruginosa and $B$. subtilis. Three hydraphiles were tested against $\mathrm{DH}_{5} \alpha$ E. coli in the preliminary report of this work. ${ }^{11}$ Two of those are included here, benzyl $\mathrm{C}_{14}(\mathbf{2})$ and benzyl $\mathrm{C}_{16}$ hydraphiles (3), along with the shorter benzyl $\mathrm{C}_{8}$ hydraphile (1). In the present study, we compare these three closely related benzyl-terminated hydraphiles that differ only in overall length, with the four structurally unrelated antibiotics noted above, against four different bacterial strains.

In each experiment, bacteria were infused with the indicated amount of hydraphile and the MIC was determined for the antibiotic in its presence. The amount of additive was always a fraction of the measured MIC value for that compound. The MIC value for Triton $\mathrm{X}-100$ was $>512 \mu \mathrm{M}$ against $\mathrm{DH}_{5} \alpha$ E. coli and the amount used in the study was arbitrarily set at $64 \mu \mathrm{M}$. The results are recorded in Table 2. Each entry reflects a minimum of 3 replicates and typically 5-10.

Table 2. Enhancement of antimicrobial activity by benzyl $\mathrm{C}_{8}, \mathrm{C}_{14}$, and $\mathrm{C}_{16}$ hydraphiles (1-3) and Triton X-100 (8) against E. coli (DH5 $\alpha$ and K-12), $P$. aeruginosa, and $B$. subtilis. 


\begin{tabular}{|c|c|c|c|c|}
\hline $\begin{array}{c}\text { Hydraphile } \\
\text { used }\end{array}$ & $\begin{array}{c}\text { [Hydraphile] } \\
(\mu M)\end{array}$ & $\begin{array}{c}\text { Antibiotic } \\
\text { used }\end{array}$ & $\begin{array}{c}\text { [Antibiotic] } \\
(\mu M)\end{array}$ & $\begin{array}{c}\text { Fold } \\
\text { Increase }\end{array}$ \\
\hline \multicolumn{5}{|c|}{ E. coli $(\mathrm{DH} 5 \alpha)$} \\
\hline $\mathrm{C}_{8}$ hydraphile (1) & $150(1 / 2[\mathrm{MIC}])$ & Kanamycin & 8 & 3 -fold \\
\hline $\mathrm{C}_{8}$ hydraphile (1) & $75(1 / 4$ [MIC]) & Kanamycin & 12 & 2-fold \\
\hline $\mathrm{C}_{8}$ hydraphile (1) & $150(1 / 2[\mathrm{MIC}])$ & Tetracycline & 1 & 5 -fold \\
\hline $\mathrm{C}_{8}$ hydraphile (1) & $75(1 / 4$ [MIC]) & Tetracycline & 2 & 2-fold \\
\hline $\mathrm{C}_{8}$ hydraphile (1) & $150(1 / 2[\mathrm{MIC}])$ & Erythromycin & 15 & 13 -fold \\
\hline $\mathrm{C}_{8}$ hydraphile (1) & $75(1 / 4[\mathrm{MIC}])$ & Erythromycin & 25 & 8-fold \\
\hline $\mathrm{C}_{8}$ hydraphile (1) & $150(1 / 2[\mathrm{MIC}])$ & Rifampicin & 3 & 18-fold \\
\hline $\mathrm{C}_{8}$ hydraphile (1) & $75(1 / 4[\mathrm{MIC}])$ & Rifampicin & 3 & 18-fold \\
\hline Triton X-100 (8) & 64 & Kanamycin & 30 & none \\
\hline Triton X-100 (8) & 64 & Rifampicin & 55 & none \\
\hline \multicolumn{5}{|c|}{$E . \operatorname{coli}(\mathrm{K}-12)$} \\
\hline $\mathrm{C}_{14}$ hydraphile (2) & $1.25(1 / 2[\mathrm{MIC}])$ & Kanamycin & 15 & 2-fold \\
\hline $\mathrm{C}_{14}$ hydraphile (2) & $0.6(1 / 4[\mathrm{MIC}])$ & Kanamycin & 30 & none \\
\hline $\mathrm{C}_{14}$ hydraphile (2) & $1.25(1 / 2[\mathrm{MIC}])$ & Tetracycline & 1 & 5 -fold \\
\hline $\mathrm{C}_{14}$ hydraphile (2) & $0.6(1 / 4[\mathrm{MIC}])$ & Tetracycline & 3 & 2-fold \\
\hline $\mathrm{C}_{14}$ hydraphile (2) & $1.25(1 / 2[\mathrm{MIC}])$ & Erythromycin & 75 & 9-fold \\
\hline $\mathrm{C}_{14}$ hydraphile (2) & $0.6(1 / 4[\mathrm{MIC}])$ & Erythromycin & 300 & 2-fold \\
\hline $\mathrm{C}_{14}$ hydraphile (2) & $1.25(1 / 2[\mathrm{MIC}])$ & Rifampicin & 0.5 & 30-fold \\
\hline $\mathrm{C}_{14}$ hydraphile (2) & $0.6(1 / 4[\mathrm{MIC}])$ & Rifampicin & 4 & 4-fold \\
\hline \multicolumn{5}{|c|}{$\begin{array}{c}\text { P.aeruginosa } \\
\end{array}$} \\
\hline $\mathrm{C}_{14}$ hydraphile (2) & $1(1 / 2[\mathrm{MIC}])$ & Tetracycline & 3.13 & 4-fold \\
\hline $\mathrm{C}_{14}$ hydraphile (2) & $0.5(1 / 4[\mathrm{MIC}])$ & Tetracycline & 6.25 & 2-fold \\
\hline $\mathrm{C}_{14}$ hydraphile (2) & $1(1 / 2[\mathrm{MIC}])$ & Erythromycin & 25 & 8-fold \\
\hline $\mathrm{C}_{14}$ hydraphile (2) & $0.5(1 / 4[\mathrm{MIC}])$ & Erythromycin & 50 & 4-fold \\
\hline $\mathrm{C}_{14}$ hydraphile (2) & $1(1 / 2[\mathrm{MIC}])$ & Rifampicin & 2.35 & 11-fold \\
\hline $\mathrm{C}_{14}$ hydraphile (2) & $0.5(1 / 4[\mathrm{MIC}])$ & Rifampicin & 4.7 & 5 -fold \\
\hline $\mathrm{C}_{16}$ hydraphile (3) & $1(1 / 2[\mathrm{MIC}])$ & Erythromycin & 25 & 8-fold \\
\hline $\mathrm{C}_{16}$ hydraphile $(\mathbf{3})$ & $0.5(1 / 4[\mathrm{MIC}])$ & Erythromycin & 50 & 4-fold \\
\hline \multicolumn{5}{|c|}{ B. subtilis } \\
\hline $\mathrm{C}_{14}$ hydraphile (2) & $0.12(1 / 4[\mathrm{MIC}])$ & Tetracycline & 1.56 & 2-fold \\
\hline $\mathrm{C}_{14}$ hydraphile (2) & $0.12(1 / 4[\mathrm{MIC}])$ & Erythromycin & 0.16 & 2-fold \\
\hline
\end{tabular}

Comparison of $\mathrm{C}_{8}$ benzyl hydraphile (1) to $\mathrm{C}_{14}$ benzyl hydraphile (2). Our initial assumption was that enhancement of antibiotic potency against bacteria was related to membrane penetration and ion transport efficacy. In our previous study, ${ }^{11}$ we did not compare channel and non-channel amphiphiles. Because earlier results showed that benzyl $\mathrm{C}_{8}$ hydraphile did not transport $\mathrm{Na}^{+}$ ions through liposomal membranes, we expected the antibiotic's MIC value to be indifferent to the presence of benzyl $\mathrm{C}_{8}$ hydraphile (1). Surprisingly, $\mathbf{1}$ enhanced the potency of kanamycin, tetracycline, erythromycin, and rifampicin against 
$\mathrm{DH}_{5} \alpha$ E. coli between 2- and 18-fold, to extents dependent on the antimicrobial that was co-administered.

The bar graph in Figure 2 compares the observed enhancements of antibiotic potency by $\mathbf{1}$ and $\mathbf{2}$. Each pair of bars reflects the potency enhancement of the indicated antibiotic, mediated by $1 / 2$ MIC of 1 or 2 against DH5a E. coli. Both compounds enhanced the potency of each antibiotic to some extent. Benzyl $\mathrm{C}_{8}$ hydraphile (1) appears marginally more active in each case than is $\mathbf{2}$. We therefore infer that the increase in antibiotic potency is independent of the compound's ability to form ion channels. Since the four antibiotics are so structurally different, it is unlikely for hydraphiles to interact with (complex with, form clusters with) the antibiotics and act as a carrier to increase their efficacy.

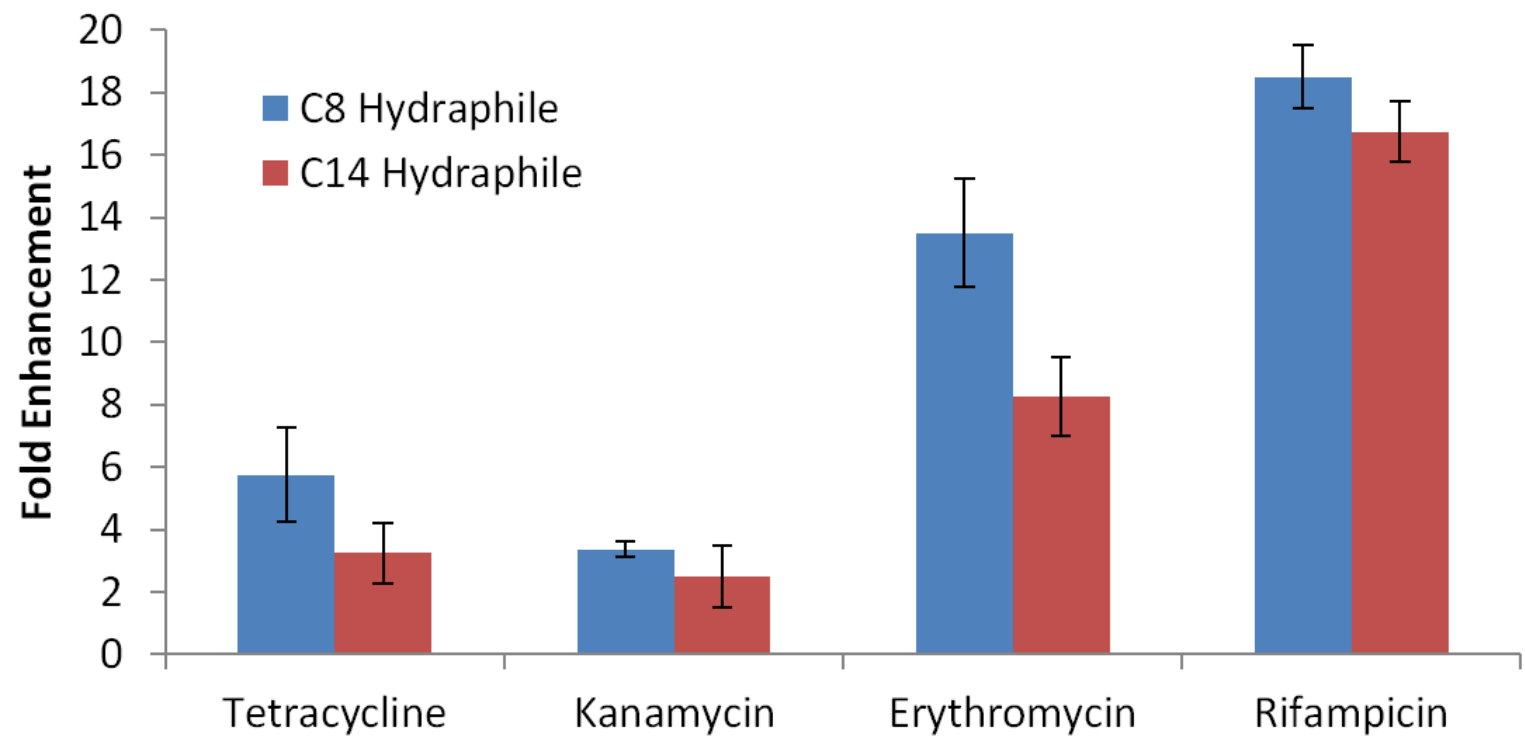

Figure 2. Fold enhancements (indicated by numbers atop the columns) of tetracycline, kanamycin, erythromycin and rifampicin by $1 / 2$ [MIC] of benzyl $\mathrm{C}_{8}(\mathbf{1})$ and benzyl $\mathrm{C}_{14}(\mathbf{2})$ hydraphiles against $\mathrm{DH}_{5}$ a E. coli. Data for benzyl $\mathrm{C}_{14}$ hydraphile were reported in reference 11 .

\section{Comparison of antimicrobial enhancement between K-12 $E$. coli and}

DH5a E. coli. As noted above, our previous work was limited to the nonpathogenic $\mathrm{DH}_{5}$ a "laboratory strain" of $E$. coli. In the preliminary report of this effort, we also reported one example each of activity assayed with $B$. subtilis and $P$. aeruginosa. A comparison of the data obtained earlier with the DH5a strain of $E$. coli with the K-12 strain was of obvious interest. The graph of Figure 3 compares the potency enhancements observed for the four antibiotics against the two bacterial strains. In all cases, benzyl $\mathrm{C}_{14}$ hydraphile (2) was the additive or mediator. The observed potency enhancements for K-12 E. coli with all four antibiotics were equal to or greater than against $\mathrm{DH}_{5} \alpha$ E. coli. In K-12 E. coli, the MIC of $\mathrm{C}_{14}$ benzyl hydraphile was 2.5 $\mu \mathrm{M}$ compared to 2.0 $\mu \mathrm{M}$ against DH5a. 
It is interesting to note that the MICs of rifampicin were different against $\mathrm{K}-12 \mathrm{E}$. coli from $\mathrm{DH}_{5}$ a E. coli. This difference has been attributed to the absence of the Oantigen from the bacterium's lipopolysaccharide shell. This enhances the membrane permeability of bacteria to hydrophobic compounds. 36

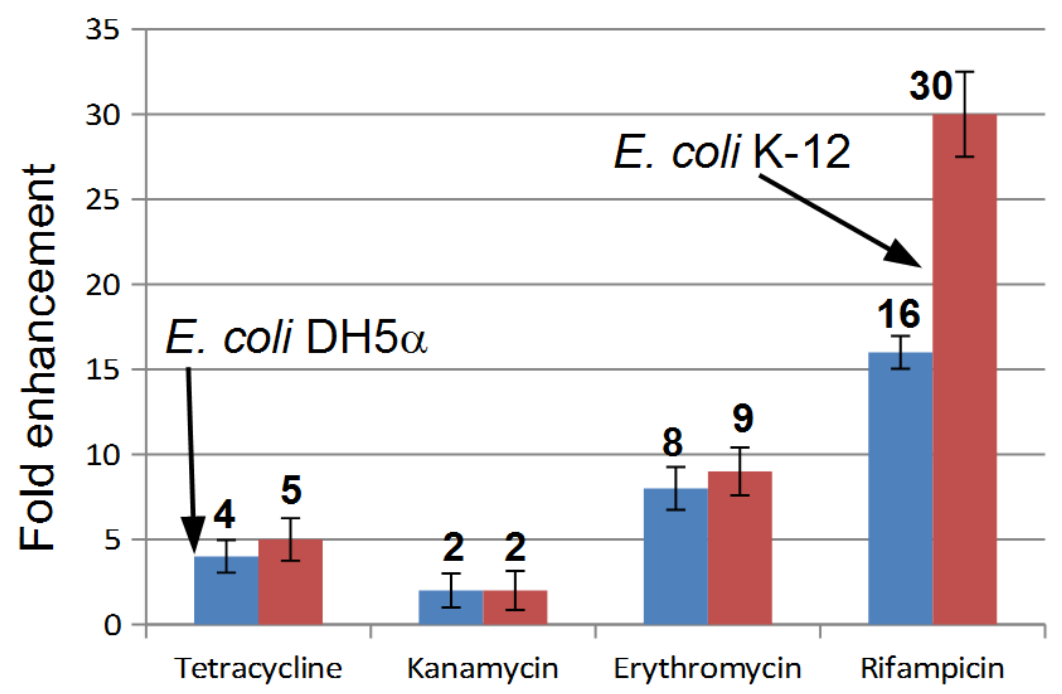

Figure 3. Fold enhancement (indicated by numbers atop the columns)of tetracycline, kanamycin, erythromycin and rifampicin mediated by $1 / 2$ [MIC] of benzyl $\mathrm{C}_{14}$ hydraphile (2) against $\mathrm{DH}_{5} \alpha E$. coli and K-12 E. coli. Data for $\mathrm{C}_{14}$ hydraphile were reported in reference 11 .

Growth curve with benzyl $C_{14}$ hydraphile and erythromycin. An obvious question concerning the results reported here is whether or to what extent, the bacteria under study suffer toxicity effects at the concentrations used. In order to address this question, we obtained growth curves for the combination of erythromycin and benzyl $\mathrm{C}_{14}$ hydraphile (2) to determine the effect of the latter on $E$. coli $\left(\mathrm{DH}_{5} \alpha\right)$. We measured the optical density of $E$. coli at $600 \mathrm{~nm}$ every 15 minutes for $12 \mathrm{~h}$ (720 min). The life cycle of $E$. coli is typically 22-23 min so the data reflect between 31 and 36 generations. By its nature, the study also revealed whether the antibiotic activity enhancement was a synergistic or additive effect. The results are shown below in Figure 4. 


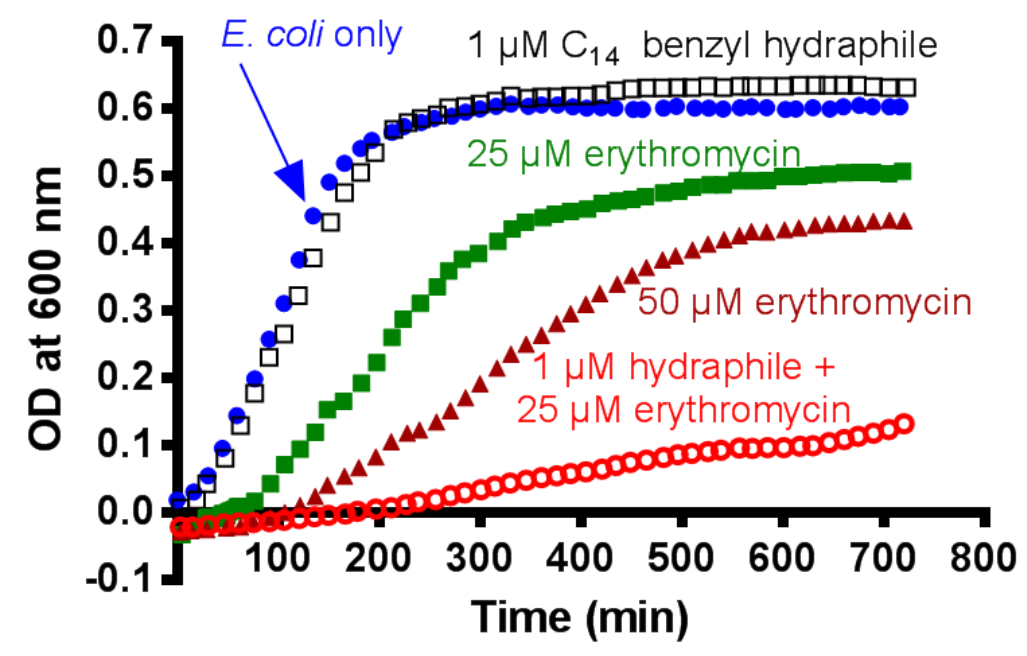

Figure 4. Graph showing the effect of benzyl $\mathrm{C}_{14}$ hydraphile (2) on the potency of erythromycin administered against $\mathrm{DH}_{5} \alpha$ E. coli. Each point represents the average of three separate determinations (error bars not shown).

It is clear from the data graphed in Figure 4 that at half MIC (open squares), benzyl $\mathrm{C}_{14}$ hydraphile (2) does not affect the growth of $\mathrm{DH}_{5} \alpha$ E. coli (filled circles). Erythromycin was administered at $25 \mu \mathrm{M}(1 / 8 \mathrm{MIC})$ and $50 \mu \mathrm{M}$ (1/4 MIC). At $25 \mu \mathrm{M}$ erythromycin, the effect on growth was minor (filled squares). When the antibiotic's concentration was doubled to $50 \mu \mathrm{M}$ (filled triangles), inhibition of growth was about twice that at the lower concentration. However, when $1 / 2-\mathrm{MIC}$ of 2 and $25 \mu \mathrm{M}$ erythromycin were combined, the growth of $E$. coli was dramatically reduced (open circles). This confirms that there is synergy between hydraphiles and antibiotics. It also indicates that hydraphiles are enhancing the potency of this antibiotic against the $E$. coli cells.

It is interesting to compare the antimicrobial potency of rifampicin with incremental amounts of benzyl $\mathrm{C}_{8}(\mathbf{1})$ and benzyl $\mathrm{C}_{14}(\mathbf{2})$ hydraphiles against $\mathrm{K}-12$ $E$. coli. The graph of Figure 4 shows that 2 enhances the potency of erythromycin against $\mathrm{DH}_{5} \alpha$ E. coli. The $\mathrm{K}-12$ strain of $E$. coli is not only more robust than $\mathrm{DH}_{5} \alpha$, it is more susceptible to rifampicin than $\mathrm{DH}_{5} \alpha \mathrm{E}$. coli is to erythromycin. The graph of Figure 5 (and Table 1) show that the MIC of rifampicin is $16 \mu \mathrm{M}$ in the absence of any hydraphile. At a concentration of $2.5 \mu \mathrm{M}$, the maximum concentration studied, $\mathbf{1}$ has no effect on rifampicin potency against the bacteria. Thus, fewer concentration studies were conducted with benzyl $\mathrm{C}_{8}$ hydraphile. When 2 is co-administered in a concentration range from o-2.5 $\mu \mathrm{M}$, clear evidence is obtained for a synergistic interaction. The dotted line in the graph connects the maxima on the two axes and would indicate a simple additive effect if followed by the experimentally determined data. 37 


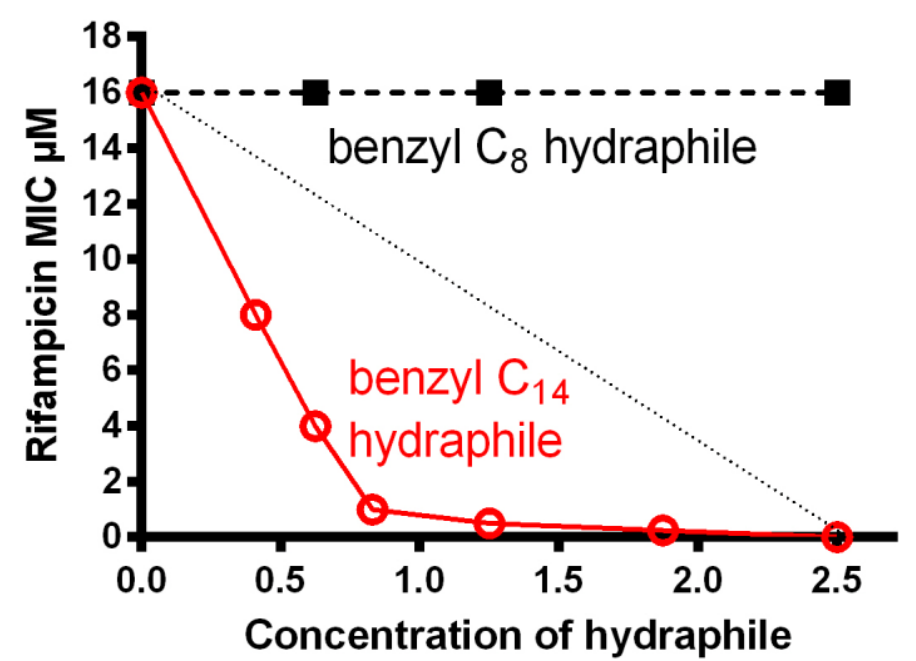

Figure 5. Graph showing the effect of added hydraphiles $\mathbf{1}$ and $\mathbf{2}$ on the potency of rifampicin against the K-12 strain of $E$. coli. The dotted line predicts the profile of an additive, rather than a synergistic, effect.

\section{Enhancement of potency against B. subtilis and Pseudomonas}

aeruginosa. Compounds 1, 2, and $\mathbf{3}$ all mediate potency enhancements when coadministered with erythromycin, kanamycin, rifampicin, or tetracycline against $\mathrm{DH}_{5} \alpha$ and K-12 E. coli. Based on the somewhat diverse literature on crown toxicity to bacteria, ${ }^{13-19}$ we anticipated that Gram positive $B$. subtilis would be the most susceptible organism to hydraphiles and the most likely to show potency enhancements when exposed to low hydraphile doses and antibiotics. In fact, the potency of either erythromycin or tetracycline against $B$. subtilis (see Table 2) was enhanced only marginally by 2 (administered at $1 / 4$ MIC). In contrast, at the $1 / 4$ MIC concentration, the potency of erythromycin against $\mathrm{DH}_{5} \alpha$ E. coli was enhanced 8-fold by benzyl $\mathrm{C}_{8}$ hydraphile $\mathbf{1}$. We note that Triton $\mathrm{X}-100$, administered at concentrations as high as $64 \mu \mathrm{M}$ showed no effect on $\mathrm{DH}_{5} \alpha$ E. coli in the presence of either kanamycin or rifampicin (data not shown).

The most dramatic increase in potency was observed for the combination of 2 at $1 / 2$ MIC with rifampicin against K-12 E. coli. This is a very encouraging result because the 30-fold potency enhancement was observed when only $1.25 \mu \mathrm{M} 2$ was coadministered. Compound $\mathbf{2}$ also enhanced the potency of rifampicin by 11-fold against $P$. aeruginosa at the same $[\mathbf{2}=] 1.25 \mu \mathrm{M}$ concentration.

Potency enhancement by 1 of 13 -fold and 18 -fold when administered against $E$. coli at $1 / 2$ MIC with erythromycin or rifampicin, respectively, was also surprising as $\mathbf{1}$ is a poor ionophore. Of course, the $1 / 2$-MIC concentration of $\mathbf{1}$ represents a much larger number of molecules than $1 / 2$ MIC of either $\mathbf{2}$ or $\mathbf{3}$. We conclude that our original hypothesis that potency enhancement correlated with pore formation or ionophoretic activity is not substantiated, at least as the sole contributor to potency enhancement. The appealing hypothesis was always somewhat speculative considering the enormous difference between the boundary layers (membrane, cell wall) of Gram negative and Gram positive bacteria. 
An alternate explanation for the enhancement is that a particular or selective interaction occurs between hydraphiles and antibiotics. Tetracycline is watersoluble and the $\mathrm{H}$-bonding ability of such a polar solvent could easily mask any supramolecular interaction. We therefore decided to exclude solvent to the greatest extent possible and undertook a mass spectrometric analysis of the interaction between $\mathbf{3}$ and tetracycline. Electrospray ionization was used to moderate the experimental conditions. However, when excess tetracycline was added to 3, no hydraphile-antibiotic adduct or cluster was observed. The major ion of $\mathbf{3}$ alone is the $[\mathbf{3} \cdot \mathrm{Na}]^{+}$adduct. The only change observed in the spectrum of $\mathbf{3}$ with the addition of tetracycline hydrochloride was the appearance of the tetracycline $\left([\mathbf{5} \cdot \mathrm{H}]^{+}\right.$and $\left.[\mathbf{5} \cdot \mathrm{DMSO} \cdot \mathrm{H}]^{+}\right)$peaks as well as various adducts of $\mathbf{3}$ with protons, sodium cations, and chloride anions.

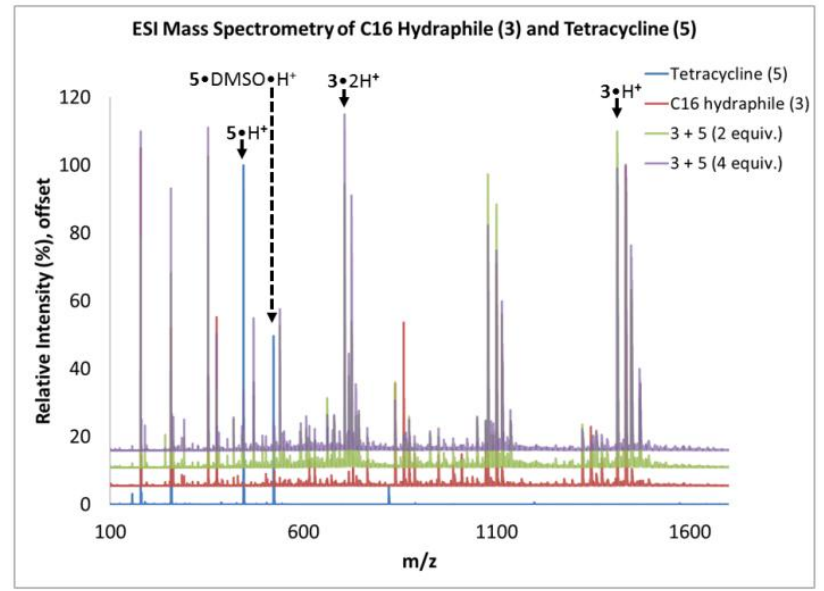

Figure 6. Electrospray mass spectra of the combination of benzyl $\mathrm{C}_{14}$ hydraphile (3) alone, tetracycline (5) alone and $\mathbf{3}$ and $\mathbf{5}$ in combination in 3:5 ratios of 2 and 4 .

A caveat in the consideration of mechanism is that the enhancements of potency apparent with $1 / 2$ or $1 / 4$ MIC of $\mathbf{1}$ involve larger amounts of compound than needed either for 2 or 3. For example, at $1 / 4$ MIC, the concentrations of 1 and 2 are $\sim 90$ $\mu \mathrm{g} / \mathrm{mL}$ and $\sim 700 \mathrm{ng} / \mathrm{mL}$. Given the $>100$-fold difference in concentration, $\mathbf{1}$ could be operating differently from $\mathbf{2}$ or $\mathbf{3}$. Further, the ability to form channels does not preclude $\mathbf{2}$ and/or $\mathbf{3}$ from interacting with the membrane to enhance permeability. There could be supramolecular interaction(s) not detected by mass spectrometry. The formation of supramolecular complexes or adducts is plausible within the low polarity regime of a bilayer membrane. Even if such interactions were detectable in a liposomal membrane where the phospholipids produce a relatively homogeneous bilayer, it is unclear that the same chemistry would occur in the more complex boundary layers of bacteria.

\section{Conclusions}

We present data that demonstrate an enhancement of antibiotic potency mediated by three hydraphiles interacting with four structurally diverse antibiotics in four different microbes. Both benzyl $\mathrm{C}_{8}(\mathbf{1})$ and $\mathrm{C}_{14}(\mathbf{2})$ hydraphiles significantly enhance the potency of antibiotics, in one case by up to 30-fold. Where significant 
potency enhancements occur, the evidence for synergy is clear. The potency enhancements observed for $\mathbf{1}$ appear to discount an exclusive ion transport-related mechanism. We infer this because $\mathbf{1}$ is inactive as $\mathrm{Na}^{+}$-transporting ion channel in liposomal and planar bilayer experiments. A more general and nonspecific increase in bacterial membrane permeability seems to be the more likely explanation for the activity, although a combination of channel formation and enhancement membrane permeability cannot be discounted.

Several mechanisms have been suggested to account for the efficacy of antimicrobial peptides in fostering the transport of hydrophobic substrates. One is that the peptide binds to the membrane to form an ion channel. $3^{8} \mathrm{~A}$ second postulate is that the peptides infiltrate the membrane according to the carpet model,39 causing extensive membrane disruption and permeability increase. A recent report of synergy between such cell penetrating peptides as magainin and polymyxin with antibiotics such as piperacillin or clarithromycin suggests enhanced membrane permeability as an important mechanistic possibility. 40 Notwithstanding, a very recent report links polymyxin permeability to a membrane receptor. ${ }^{41}$ An increase in permeability mediated by hydraphiles seems plausible in the present case, but channel formation may also alter membrane structure or function or both. Studies are underway with structurally related amphiphiles not known to form channels to further define the scope of such enhancements.

\section{Experimental section}

Hydraphiles. Benzyl hydraphiles having spacer chains of 8-14- and 16methylene groups have been prepared and reported previously. ${ }^{21,22}$ Benzyl $\mathrm{C}_{8}, \mathrm{C}_{14}$ and $\mathrm{C}_{16}$ hydraphiles for use in this study were synthesized according to a recently reported procedure. ${ }^{24}$ All the hydraphiles were dissolved in DMSO before use. The final concentration of DMSO in each experiment was kept constant at 0.5\%-by volume whether or not the co-solvent was required for solubility.

Antibiotics and bacteria used. All antibiotics were obtained from SigmaAldrich Chemical Company. Rifampicin and erythromycin were dissolved in DMSO before use. Tetracycline and kanamycin were dissolved in autoclaved milli$\mathrm{Q} \mathrm{H}_{2} \mathrm{O}$. The compounds purchased were the purest available and were used as received.

E. coli (DH5a and K-12), B. subtilis and P. aeruginosa were obtained from the American Type Culture Collection (ATCC) and were used for MIC and coadministration procedures. All bacteria were cultured in L.B. Miller media and used at exponential growth phase as outlined in the MIC procedure below.

Minimal inhibitory concentration (MIC). The MIC and co-administration studies were performed according to the procedure outlined in Clinical and Laboratory Standards Institute. ${ }^{28}$ Bacteria were grown overnight from one colony forming unit (CFU) in L.B. Miller media. Compounds were prepared by serial dilutions in either DMSO or milli-Q $\mathrm{H}_{2} \mathrm{O}$. The compound or antibiotic [10 $\left.\mu \mathrm{L}\right]$ was added to $1970 \mu \mathrm{L}$ of L.B. Miller media in the test tubes. The bacteria were knocked back to O.D. $(600 \mathrm{~nm})=0.600$ before use and $20 \mu \mathrm{L}$ of dispersion was added to 
each test-tube. The test tubes were vortexed before and after adding bacteria and incubated overnight at $37^{\circ} \mathrm{C}$ and $200 \mathrm{RPM}$, before collecting the results. Visual turbidity of the liquid in the test tubes was used to determine growth or no growth. The lowest concentration that inhibited the growth of bacteria completely, was considered to be the MIC. The data were reproduced at least three times at the MIC concentration.

Co-administration of hydraphiles and antibiotics. The co-administration of hydraphiles and antibiotics experiments were performed as outlined in the Clinical and Laboratory Standards Institute protocols. ${ }^{28}$ The bacteria were prepared at O.D. $600 \mathrm{~nm}=0.600$, as outlined in the MIC procedure above. The MIC of each antibiotic was determined by using the serial dilution technique in the presence of an amount of hydraphile determined to be $1 / 2$ or $1 / 4$ of the hydraphile's MIC. In a test tube, L.B. Miller media was added followed by hydraphiles and antibiotics. The final volume of compounds added was kept constant at 0.5\%-by volume (DMSO or $\mathrm{dH}_{2} \mathrm{O}$ ) as needed. The bacteria were knocked back and $20 \mu \mathrm{L}$ of the dispersion was added to each test-tube. The test tubes were incubated overnight at $37^{\circ} \mathrm{C}$ while stirring at 200 RPM, before collecting the results. Growth or no growth of the bacteria was determined by visual inspection. The MIC of antibiotics in the presence of hydraphiles was replicated a minimum of three times.

Growth curve. Growth curves were performed with benzyl $\mathrm{C}_{14}$ hydraphile and erythromycin against $\mathrm{DH}_{5} \alpha E$. coli. The growth curves were performed in a $2 \mathrm{~mL}$ culture. E. coli was grown overnight from one CFU in L.B. Miller media and knocked back to O.D. $600 \mathrm{~nm}=0.600$ before use. Media was added (L.B. Miller) to a test tube followed by desired concentration of hydraphile or erythromycin or a combination of both. The concentration (volume) of DMSO was kept constant at $0.5 \%$-by volume. To each test tube, knocked back $E$. coli was added and the samples were vortexed. Contents of the test tubes were incubated at $37^{\circ} \mathrm{C}$ and 200 RPM and its optical density was determined at $\lambda=600 \mathrm{~nm}$ every 15 minutes for 12 hours. The results are presented as optical density $v s$. time.

Electrospray ionization mass spectrometry. Spectra were obtained on a JEOL JMS-700 mass spectrometer. Samples were injected directly into the instrument at $1 \mathrm{~mL} / \mathrm{min}$ and ionized by electrospray with a tip voltage of $2 \mathrm{kV}$. A mass range of 100 to $2400 \mathrm{~m} / \mathrm{z}$ was scanned in the positive polarity mode. No significant peak was observed past $1700 \mathrm{~m} / \mathrm{z}$. Benzyl $\mathrm{C}_{16}$ hydraphile 3 (in DMSO, 0.25-0.5 mM final concentration) was added to tetracycline 5 (hydrochloride salt in 18.2 $\mathrm{M} \Omega \mathrm{H}_{2} \mathrm{O}, 1 \mathrm{mM}$ final concentration). Controls were performed with hydraphile 3 and antibiotic 5 alone. In each case the final DMSO: $\mathrm{H}_{2} \mathrm{O}$ ratio was 9:1 by volume.

Acknowledgement. We thank the National Science Foundation for a grant CHE 1307324 and the University of Missouri for a Fastrack grant that supported portions of the work reported here.

\section{References}


Lesch, J. E., The First Miracle Drugs: How the Sulfa Drugs Transformed Medicine. Oxford University press: Oxford, 2007, $364 \mathrm{pp}$.

Shlaes, D. M., Antibiotics: The Perfect Storm. Springer Verlag: New York, 2010, 106 pp.

CDC, Antibiotic Resistance Threats in the United States, 2013. ed.; Centers for Disease Control and Prevention: Washington DC, 2013, $113 \mathrm{pp}$. World Health Organization, Antimicrobial Resistance Global Report on Surveillance, Geneva, 2014, 257 pp.

Ling, L. L.; Schneider, T.; Peoples, A. J.; Spoering, A. L.; Engels, I.; Conlon, B. P.; Mueller, A.; Schäberle, T. F.; Hughes, D. E.; Epstein, S.; Jones, M.; Lazarides, L.; Steadman, V. A.; Cohen, D. R.; Felix, C. R.; Fetterman, K. A.; Millett, W. P.; Nitti, A. G.; Zullo, A. M.; Chen, C.; Lewis, K., Nature 2015, $517,455-459$.

King, A. M.; Reid-Yu, S. A.; Wang, W.; King, D. T.; De Pascale, G.; Strynadka, N. C.; Walsh, T. R.; Coombes, B. K.; Wright, G. D., Nature 2014, 510, 503-6.

(a) Dutton, C. J.; Haxell, M. A.; McArthur, H. A. I.; Wax, R. G., Peptide Antibiotics: Discovery, Modes of Action, and Applications. ed.; Marcel Dekker, Inc.: New York, 2002; p 296. (b) Zasloff, M., N. Engl. J. Med. 2002, 347, 1199-1200. (c) Vaara, M., Curr. Opin. Pharmacol. 2009, 9, 571-6.

Zasloff, M., Proc. Natl Acad. Sci. USA 1987, 84, 5449-5453.

Findlay, B.; Zhanel, G. G.; Schweizer, F., Antimicrob. Agents Chemother. 2010, 54, 4049-58.

Zhou, Y.; Peng, Y., Exp Ther Med 2013, 6, 1000-1004. Atkins, J. L.; Patel, M. B.; Cusumano, Z.; Gokel, G. W., Chem. Commun. 2010, 46, 8166-7.

Gokel, G. W., Hydraphiles: Design, Chem. Commun. 2ooo, 1-9. Leevy, W. M.; Weber, M. E.; Schlesinger, P. H.; Gokel, G. W., Chem. Commun. 2005, 89-91.

(a) Pedersen, C. J., J. Am. Chem. Soc. 1967, 89, 7017-36. (b) Pedersen, C. J., Science 1988, 241, 536-40.

Leong, B. K.; Ts'o, T. O.; Chenoweth, M. B., Toxicol. Appl. Pharmacol. 1974, 27, 342-54.

Hendrixson, R. R.; Mack, M. P.; Palmer, R. A.; Ottolenghi, A.; Ghirardelli, R. G., Toxicol. Appl. Pharmacol. 1978, 44, 263-8.

17 (a) Kato, N.; Ikeda, I.; Okahara, M.; Shibasaki, I., Res. Soc. Antibac. Antifung. Agents Jpn. [Bokin Bobai] 1980, 8, 532-533. (b) Kato, N., Kenkyu Kiyo - Konan Joshi Daigaku 1985, 585-96.

18 Yagi, K.; Garcia, V.; Rivas, M. E.; Salas, J.; Camargo, A.; Tabata, T., J. Inclusion Phenom. 1984, 2, 179-84.

(a) Konup, L. A.; Konup, I. P.; Sklyar, V. E.; Kosenko, K. N.; Gorodnyuk, V. P.; Fedorova, G. V.; Nazarov, E. I.; Kotlyar, S. A., KhimikoFarmatsevticheskii Zhurnal 1989, 23, 578-583 (Chem. Abstr. 111:112190). (b) Devinsky, F.; Lacko, I.; Inkova, M., Die Pharmazie 1990, 45, 140. (c) Eshghi, H.; Rahimizadeh, M.; Zokaei, M.; Eshghi, S.; Eshghi, S.; Faghihi, Z.; Tabasi, E.; Kihanyan, M., Eur. J. Chem. 2011, 2, 47-5O. (d) Zaim, O.; 
Aghatabay, N. M.; Gurbuz, M. U.; Baydar, C.; Dulger, B., J. Incl. Phenom. Macrocycl. Chem. 2014, 78, 151-159. (e) Ozay, H.; Yildiz, M.; Unver, H.; Dulger, B., Asian J. Chem. 2011, 23, 2430-2436. (f) Le, T. A.; Truong, H. H.; Thi, T. P. N.; Thi, N. D.; To, H. T.; Thi, H. P.; Soldatenkov, A. T., Mendeleev Commun. 2015, 25, 224-225.

20 Leevy, W. M.; Donato, G. M.; Ferdani, R.; Goldman, W. E.; Schlesinger, P. H.; Gokel, G. W., J. Am. Chem. Soc. 2002, 124, 9022-3.

21 (a) Murray, C. L.; Gokel, G. W., Cation flux dependence on carbon chain length in tris(macrocycle) channels as assessed by dynamic 23Na NMR studies in phospholipid bilayers. Chem. Commun. 1998, 2477-2478. (b) Weber, M. E.; Schlesinger, P. H.; Gokel, G. W., Dynamic Assessment of Bilayer Thickness by Varying Phospholipid and Hydraphile Synthetic Channel Chain Lengths. J. Am. Chem. Soc. 2005, 127, 636-642. Gokel, G. W., Hydraphiles: Design, Synthesis, and Analysis of a Family of Synthetic, Cation-Conducting Channels, Chem. Commun. 200o, 1-9.

23 Curvey, N. S.; Luderer, S. E.; Walker, J. K.; Gokel, G. W., Synthesis 2014, 46, 2771-2779.

24 Gourevitch, A.; Tynda, J. M.; Puglisi, T. A.; Lein, J., Antibiot. Annu. 1958, 6, 784-9.

25 Gomazkov, O. A., Fed. Proc. Transl. Suppl. 1964, 23, 876-8.

26 (a) Brisson-Noel, A.; Trieu-Cuot, P.; Courvalin, P., J. Antimicrob. Chemother. 1988, 22 Suppl B, 13-23. (b) Usary, J.; Champney, W. S., Mol. Microbiol. 2001, 4O, 951-62.

27 Yarbrough, L. R.; Wu, F. Y.; Wu, C. W., Biochemistry 1976, 15, 2669-76.

28 Ingen, J. v.; Aarnoutse, R. E.; Donald, P. R.; Diacon, A. H.; Dawson, R.; Balen, G. P. v.; Gillespie, S. H.; Boeree, M. J., Clin. Infect. Diseases 2011, 52, e194-e199.

29 Johns Hopkins ABX Guide Diagnosis and Treatment of Infectious Diseases, $3^{\text {rd }}$ Edition, 2012, pages 541, 588.

30 MIC, Clinical and Laboratory Standards Institute: Mo7-A9, Methods for dilution antimicrobial susceptibility tests for bacteria that grow aerobically; Approved standard, ISBN 1-56238-784-7, www.clsi.org 2012, Ninth Edition.

31 (a) Schlieper, P.; De Robertis, E., Arch. Biochem. Biophys. 1977, 184, 2048. (b) Rostovtseva, T. K.; Bashford, C. L.; Lev, A. A.; Pasternak, C. A., J. Membr. Biol. 1994, 141, 83-90.

32 Schlieper, P.; De Robertis, E., Arch. Biochem. Biophys. 1977, 184, 204-8.

33 Rostovtseva, T. K.; Bashford, C. L.; Lev, A. A.; Pasternak, C. A., J. Membr. Biol. 1994, 141, 83-90.

34 Costerton, J. W., The Biofilm Primer. Springer Verlag: Heidelberg, 2007; $199 \mathrm{pp}$.

35 Gokel, G. W.; Gokel, M. R.; Negin, S.; Patel, M. B. PCT WO 2015/188140 A1, published December 15, 2015.

36 (a) Nikaido, H.; Vaara, M., Microbiol. Rev. 1985, 49, 1-32. (b) Nikaido, H., Microbiol. Mol. Biol. Rev. 2003, 67, 593-656.

37 Tallarida, R. J., Drug Synergism and Dose-Effect Data Analysis. Chapman \& Hall: Boca Raton, 267 pp., 2000; 267 pp. 
38 Reddy, K. V.; Yedery, R. D.; Aranha, C., Int. J. Antimicrob. Agents 2004, 24, 536-47.

39 Shai, Y.; Oren, Z., Peptides 2oo1, 22, 1629-41.

40 Zhou, Y.; Peng, Y., Exp. Ther. Med. 2013, 6, 1000-1004.

41 Petrou, V. I.; Herrera, C. M.; Schultz, K. M.; Clarke, O. B.; Vendome, J.; Tomasek, D.; Banerjee, S.; Rajashankar, K. R.; Dufrisne, M. B.; Kloss, B.; Kloppmann, E.; Rost, B.; Klug, C. S.; M. Stephen Trent; Shapiro, L.; Mancia, F., Science 2016, 351, 608-612. 